\title{
Inverted Transitional Cell Papilloma
}

National Cancer Institute

\section{Source}

National Cancer Institute. Inverted Transitional Cell Papilloma. NCI Thesaurus. Code C4118.

A benign papillary neoplasm composed of transitional cells and characterized by an endophytic growth pattern. 